\title{
ETHICS IN PUBLIC SERVICES \\ (A Survey in the Regency of Sleman, the Regency of Bantul, and the City of Yogyakarta, in the Province of the Special Region of Yogyakarta, Indonesia)
}

\author{
Ulung Pribadi \\ Universitas Muhammadiyah Yogyakarta \\ ulungpribadi@ymail.com
}

\begin{abstract}
The purpose of the study is to investigate the ethical behaviour of public servants in providing public services. The Method of this study is to survey a sample of citizens who had received public service at the Department of Licenses of the regency of Sleman, of the regency of Bantul, and the city of Yogyakarta, in the Province of the Special Region of Yogyakarta, Indonesia. The findings of the study show that different independent variables have a variety of strong or weak influence on the dependent variable. The theoretical implication of this study is that there is now an empirical test on the effects of independent variables on the dependent variable. The practical implication of this study is that it can serve to inform public officials of the need to prioritize on improving aspects which at the time of this study has the least influence on public ethical behavior. The limitation of this study is that the samples of the data collected are limited to three public agencies, and the number of respondents of this study is limited as well. The originality of the study is that it is able to contribute to the understanding of how much influence the variables have on the ethical behaviour of public servants.
\end{abstract}

Keywords: Ethics; Public servants; Local government; Democratic procedures; Local autonomy; Government leadership; Organizational structure; Laws; Salary; Culture; Religious beliefs

\section{Introduction}

The public services that Indonesian local governments provide for their citizens are generally of meager standards. The Ombudsman of Republic of Indonesia (2017) evaluated the local governments' compliance in implementing service standards annually, that was showed that only $13(12.14 \%)$ government regencies are compliant ('green zone'), that $46(42.99 \%)$ regencies are less compliant ('yellow zone'), and that 98 (44.85\%) regencies are not compliant ('red zone'). In addition, there are 15 (33.33\%) government cities in the 'green zone', $22(48.89 \%)$ cities in the 'yellow zone', and $8(17.78 \%)$ cities in the 'red zone'. Consequently, it is concluded that the majority of local governments are not capable of delivering satisfactory public services. According to leading experts, public servant behaviour is the main cause of the poor condition of the public services in Indonesia. Budiman, Roan, and Callan (2013) stated that corrupt behaviour of the civil servants have been existed since the Suharto era's New Order Regime.

The two main programs of the Indonesian bureaucratic reforms are: 1) state apparatus and human resources reforms, that is, to promote among public servants some level of commitment, integrity, neutral attitude, competency, dedication, and professionalism; and 2) 
public service reform, that is, to provide good public services based on needs and expectations of the society (Gaus et al., 2017).

In order to enhance public servants' good behaviour in providing public services, the central government has published Act no. 25, 2009 regarding public services. Following up on the Act, the central government issued President Regulation No. 81, 2010 on the Grand Design of Bureaucratic Reform. In addition, the Minister of State Apparatus and Bureaucratic Reform launched Regulation No. 39, 2012 on the Guidelines for Work Culture Development. Furthermore, in the Special Region of Yogyakarta, the government organizational culture has been consolidated through the passing of the Regulation of the Governor of the Special Region of Yogyakarta No. 72, 2008 and No. 53, 2014.

Scientific studies regarding public services in relation to ethics in Indonesia unfortunately are very lacking. Idris et al. (2015) assessed public service practices. Nugraha et al. (2015) showed that the quality of the public trade licensing service is still low. Mahfud (2016) found that problems with morality were the main factors of the low quality public service. Hoadley and Hatti (2016) studied corruption in India and Indonesia. Prabowo et al. (2017) analysed public service provision in Indonesia Wardhani et al. (2017) studied the correlation between public spending, good governance, and their outcomes.

However, different from those studies mentioned above, this study focuses on testing the influence of a series of independent variables, including democratic procedures, local autonomy/decentralization, leadership, organizational structure, laws/acts, salary/incentives, culture, and religious beliefs, on the dependent variable of the ethical behaviour of the public servants in providing public services in the regency of Sleman, the regency of Bantul, and the city of Yogyakarta.

\section{Ethics in public services}

Ethics are generally defined as things that are related to the question of right and wrong and also to moral duties and obligations. According to Omisore and Adeleke (2015), someone who implements a highly ethical behavior will eventually become a good person intrinsically, and his good deeds will come from within. According to Stout and Love (2013), whole approach to public ethics based on qualitative answerability stands to result in good outcomes for governance. Meanwhile, Johnson (2014) stated that public service values of ethics include: allegiance, confidentiality, avoiding conflict of interest, faithfulness, fidelity, giving proper credit, non-discrimination, not self-laudatory. According to Sebola (2014), there was a discrepancy between native cultural ethos and ethical frameworks based on rational doctrines.

According to the code of conduct of public servants of the Indonesian government in Act No. 25, 2009, good ethical behaviour includes being fair and non-discriminatory; being careful, polite and friendly; being firm, reliable and unobstructive in making decisions; behaving professionally and not complicating matters; adhering to the legitimate and reasonable orders of the superior; upholding the values of accountability and integrity in organizing institutions; not divulging information and documents that must be kept secret; being open minded and striving to avoid conflicts of interest; wholeheartedly carrying out his/her obligations; not misusing facilities and infrastructure of public services; being 
proactive in providing correct information to meet public interest; not abusing their position and authority, acting appropriately, and not deviating from standard procedure.

Factors can influence ethical behaviours are firstly, the individual characteristics of public servants (Richardson and Nigro in Radhika, 2012:25), mental attitude (Bailey in Radhika, 2012:25 ), virtues (Dimock, Dobel, Gregory, Hart in Radhika, 2012:25), and professional values (Van Wart in Radhika, 2012:25). Secondly, it is the organizational structure (Denhardt, Thomson in Radhika, 2012:25). Thirdly, it is culture (Schein in Radhika, 2012:25), leadership (Scott, Schein, Ott in Radhika, 2012:25), and employees discuss ethical problems (Bruce in Radhika, 2012:25).

Furthermore, Cowell et al.(2014) explained that ethics relate to democracy and good governance. In addition, Villoria et al. (2013) stated that ethics relate to satisfying government services. Walumbwa et al. (2011), Mayer et al. (2012), and Resick et al. (2013) stated that ethical leadership affects behaviour of subordinates. Beeri et al. (2013) and Hassan et al. (2013) assessed effects of ethical leadership. Hassan et al. (2014) assessed ethical leadership. Moreover, Hassan et al. (2014) mentioned that leaders reduced absenteeism. Hassan et al. (2014) hoped that more researchers would explore influence of leadership in facilitating ethical behavior. Omisore and Adeleke (2015) discussed challenges of work ethics. Schein (in Radhika, 2012) gave some evidence that ethics are determined by organizational culture. Omisore and Adeleke (2015) explained that ethical behaviour is intrinsic. Furthermore, Omisore and Adeleke (2015) cited ethical conduct is influenced by the cultural norm. Moreover, Omisore and Adeleke (2015) showed that ethics is affected by their social interactions.

Based on the context of the Indonesian local governments, the following hypotheses can be proposed:

H1: democratic procedures influence ethical behaviour of public servants in providing services in local government.

H2: autonomy/decentralization influences ethical behaviour of public servants in providing services in local government.

H3: leadership influences ethical behaviour of public servants in providing services in local government.

H4: organizational structure influences ethical behaviour of public servants in providing services in local government.

H5: laws/acts passed influences ethical behaviour of public servants in providing services in local government.

H6: salary/incentives influences ethical behaviour of public servants in providing services in local government.

H7: culture influences ethical behaviour of public servants in providing services in local government.

H8: religious beliefs influences ethical behaviour of public servants in providing services in local government.

\section{Research method}

In order to investigate the subject, this study takes a case study in three local governments in the special region of Yogyakarta, which are the regency of Sleman, the regency of Bantul, 
and the city of Yogyakarta. This study uses a sample of citizens who received public service at the Department of Licenses of each of the three local governments, so that this study can get objective answers for the questionnaires. Based on the data collected from the regencies and the city, the population of this study consists of 400 persons on average every month. Characteristic of the population is relatively homogeny. It means that persons who received services from the local governments have same interest that is to obtain licenses from the public agencies. Because of the homogeneous population, this study uses simple random sampling technique. Based on the technique, sample of this study is 10 percent of the population. Therefore, the total sample of this study is 120 respondents of the three regions.

The respondents' perception towards the independent variables of democratic procedures, autonomy/decentralization, leadership, organizational structure, laws/acts passed, salary/incentives, culture, and religious beliefs and towards the dependent variable of ethical behaviour of the public servants is measured using a Likert 5 scale: 1 - indicating strong disagreement, 2 - disagreement, 3 - neutral, 4 - agreement, and 5 - strong agreement. This study utilizes correlation and linear regression analyses effectively in order that the hypotheses on the relationship between the independent variables and the dependent variable can be examined.

\section{Results}

The results of this study regarding ethical behaviour of public servants in providing public services in regency of Sleman, regency of Bantul, and city of Yogyakarta are described below:

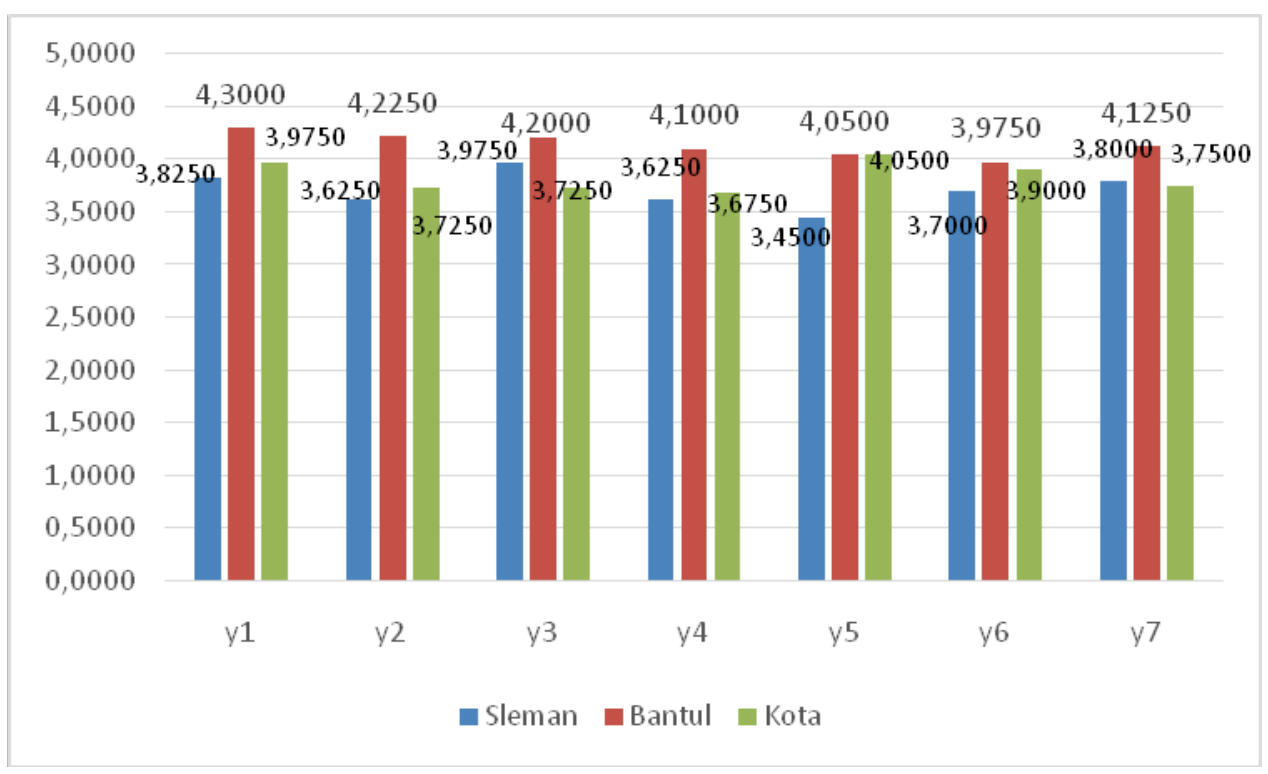

Figure 1 Descriptive Statistics of Ethical Behaviour of the Public Servants

The empirical data that is described in the figure 1 shows the perception of the respondents towards ethical behaviour of the public servants in providing public services, which includes: being fair and non-discriminatory (y1); being careful, polite, friendly, and being firm, reliable, and unobstructive in making decisions (y2); behaving professionally and 
not complicating matters (y3); upholding the values of accountability and integrity of organizing institutions (y4); being proactive in providing correct information to meet public interest (y5); not misusing facilities and infrastructure of public services (y6); and wholeheartedly carrying out his/her obligations (y7).

The data shows: firstly, the average for the ethical behaviour of the public servants in providing public services in regency of Sleman is at 3.71 in the range of $1-5$ (interval of 1 2.33 is 'low', $2.34-3.67$ is 'middle', and $3.68-5$ is 'high'). It means that the ethical behaviour of the public servants in regency of Sleman is in the 'high' category. Secondly, the average for the ethical behaviour of the public servants in the regency of Bantul is at 4.14. It means that the ethical behaviour of the public servants in the regency of Bantul is also in the 'high' category. Thirdly, the average for the ethical behaviour of the public servants in the city of Yogyakarta is at 3.83. It means that the ethical behaviour of the public servants in city of Yogyakarta is in the 'high' category as well. Fourth, the average for the ethical behaviour of the public servants in all three local governments is at 3.89. It means that the ethical behaviour of the public servants in the three local governments together is in the 'high' category. Fifth, though they are all in the 'high' category, the highest to the lowest average score for ethical behaviour of the public servants begins from those in the regency of Bantul, followed by those in the city of Yogyakarta, and then finally by those in the regency of Sleman.

The results of the correlation between the independent variables and the dependent variable can be seen in table I below:

Table I

Correlation between Independent Variables and Dependent Variable

\begin{tabular}{|l|c|c|c|}
\hline \multirow{2}{*}{\multicolumn{1}{|c|}{ Independent Variables }} & \multicolumn{3}{c|}{ Dependent Variable (Ethics) } \\
\cline { 2 - 4 } & $\begin{array}{c}\text { Regency of } \\
\text { Sleman }\end{array}$ & $\begin{array}{c}\text { Regency of } \\
\text { Bantul }\end{array}$ & $\begin{array}{c}\text { City of } \\
\text { Yogyakarta }\end{array}$ \\
\hline Democratic procedures (x1) & 0,285 & $0,554^{* *}$ & 0,227 \\
\hline $\begin{array}{l}\text { Local autonomy/ } \\
\text { decentralization(x2) }\end{array}$ & $-0,046$ & $0,607^{* *}$ & $0,414^{* *}$ \\
\hline Leadership (x3) & $0,347^{*}$ & $0,666^{* *}$ & 0,280 \\
\hline Organization structure (x4) & $0,403^{* *}$ & $0,745^{* *}$ & 0,246 \\
\hline Laws/acts passed (x5) & 0,253 & $0,707^{* *}$ & $0,396^{*}$ \\
\hline Salary/incentives(x6) & 0,269 & $0,496^{* *}$ & 0,062 \\
\hline Culture (x7) & $0,385^{*}$ & $0,732^{* *}$ & 0,034 \\
\hline Religious beliefs (x8) & $0,444^{* *}$ & $0,661^{* *}$ & 0,164 \\
\hline
\end{tabular}

*. Correlation is significant at the 0.05 level (2-tailed).

**. Correlation is significant at the 0.01 level (2-tailed).

Table I presents the correlation of the eight independent variables and the one dependent variable. The first independent variable, 'democratic procedures', has a strong positive 
relationship with the dependent variable in the regency of Bantul. In contrast, this independent variable shows negative relationship with the dependent variable in the city of Yogyakarta as well as the regency of Sleman. The 'local autonomy/decentralization' variable, is shown to have a strong positive relationship with the dependent variable in Bantul and in Yogyakarta. Meanwhile, this independent variable has a negative relationship with public ethics in Sleman. The 'leadership' variable shows a positive relationship with public ethics in the regency of Sleman, and a strong positive relationship in Bantul. Nevertheless, in Yogyakarta, this variable has a negative relationship with public ethics. The 'organizational structure' variable has a strong positive relationship with public ethics in Sleman and Bantul, but it has a negative relationship with public ethics in the city of Yogyakarta. The 'laws/acts passed' variable shows a strong positive relationship with public ethics in regency of Bantul, and a positive relationship in Yogyakarta. However, it has a negative relationship with public ethics in Sleman. The 'salary/incentives' variable, meanwhile, has a negative relationship with public ethics in Sleman and in Yogyakarta. By contrast, this variable has a strong positive relationship with public ethics Bantul. The 'culture' variable has a positive relationship with public ethics in regency of Sleman and a strong positive relationship in regency of Bantul, although in Yogyakarta, its correlation with public ethics is negative. Finally, the 'religious beliefs' variable has a strong relationship with the ethics both in Sleman and Bantul, although the relationship is negative in city of Yogyakarta.

The results of the linear regression analysis for all the hypotheses can be shown in table II below:

Table II

Results of Linear Regression Analysis for all Hypotheses

\begin{tabular}{|c|c|c|c|}
\hline \multirow[b]{2}{*}{ Independent Variables } & \multicolumn{3}{|c|}{ Linear Regression } \\
\hline & $\begin{array}{l}\text { Regency of } \\
\text { Sleman }\end{array}$ & $\begin{array}{c}\text { Regency of } \\
\text { Bantul }\end{array}$ & $\begin{array}{c}\text { City of } \\
\text { Yogyakarta }\end{array}$ \\
\hline Democratic procedures $(\mathrm{x} 1)$ & 0,196 & 0,823 & 0,595 \\
\hline $\begin{array}{l}\text { Local autonomy/decentralization } \\
(\mathrm{x} 2)\end{array}$ & 0,315 & 0,205 & 0,249 \\
\hline Leadership (x3) & 0,864 & 0,241 & 0,370 \\
\hline Organizational structure (x4) & 0,327 & 0,094 & 0,174 \\
\hline Laws/acts passed (x5) & 0,625 & 0,258 & 0,361 \\
\hline Salary/incentive(x6) & 0,873 & 0,695 & 0,137 \\
\hline Culture (x7) & 0,929 & 0,246 & 0,214 \\
\hline Religious belief (x8) & 0,223 & 0,102 & 0,654 \\
\hline $\mathrm{F}$ & 1,558 & 9,193 & 1,814 \\
\hline $\mathrm{R}^{2}$ & 0,287 & 0,703 & 0,319 \\
\hline $\mathrm{AR}^{2}$ & 0,103 & 0,627 & 0,143 \\
\hline
\end{tabular}


The table II presents the results of the linear regression analysis for the hypotheses. From the table above, this study was able to find several new discoveries.

First, regarding the independent variable democratic procedures, it is one variable that only weakly influences the ethical behaviour of the public servants in the regency of Sleman, but has a rather strong influence in the city of Yogyakarta, and a very strong influence in the regency of Bantul. Secondly, in sharp contrast, while the variable 'local autonomy/decentralization' has a rather strong influence on ethical behaviour in the regency of Sleman, its influence on public servants' behavior is very weak in the regency of Bantul and the city of Yogyakarta. Third, 'leadership' influences the ethical behaviour of the public servants very strongly in regency of Sleman, but only rather strongly in city of Yogyakarta, and very weakly in the regency of Bantul. Fourth, the variable 'organizational structure' only has a rather strong influence on ethical behaviour in the regency of Sleman, and a very weak influence in the regency of Bantul and the city of Yogyakarta. Fifth, 'the law/acts passed' variable has a rather strong influence in both the regency of Sleman and the city of Yogyakarta, but has a weak influence in the regency of Bantul. Sixth, while the 'salary/incentives' variable strongly influences ethical behaviour in the regency of Sleman, it only rather strongly influences ethical behavior in the regency of Bantul, and weakly so in the city of Yogyakarta. Seventh, 'the culture' independent variable has a strong influence on the ethical behaviour in regency of Sleman, but has a weak influence in Bantul and Yogyakarta. Finally, eighth, though the influence of the variable 'religious beliefs' on the ethical behaviour is weak in the regency of Sleman and the regency of Bantul, it is rather strong in city of Yogyakarta.

\section{Discussion}

The very strong influence of the 'democratic procedures' variable on ethical behaviour in the regency of Bantul and the rather strong influence that it has in city of Yogyakarta are evidence for the assumption made by Radhika (2012) who stated that the political construct, policies, and democratic accountability are main determinants of administrative conduct in the public sector, and for the statement by Cowell et al. (2014) that democracy and good governance are critical factors of ethics.

The weak influence that the 'local autonomy/decentralization' variable has on the ethical behaviour in all three administrations is contrary to scholars' opinion (Radhika, 2012; Villoria et al., 2013) that the participation of citizens and users of government's public services in the context of a civil society and a decentralized governance can enhance ethical behaviour of the public servants.

The fact that the 'leadership' variable strongly influences the ethical behaviour in the regency of Sleman and rather strongly influences the same in the city of Yogyakarta is a testament to the assertion made by Scott, Schein, and Ott, and Bruce (in Radhika 2012:25) that leadership is important in the development, maintenance, and adaptation of organizational culture and in the improvement of personal standards and employee education, and that it will encourage adoption of ethical behaviour. The significance of leadership on ethical behaviour and on the commitment of subordinates in public and government organizations was also proven by Walumbwa et al. (2011), Mayer et al. (2012), Resick et al. (2013), Beeri et al. (2013), and Hassan et al. (2013), Hassan et al. (2014). 
The strong influence of the government 'organizational structure' variable on the ethical behaviour in the regency of Sleman is a validation of the opinions from scholars such as Denhardt and Thomson (in Radhika, 2012:25), Richardson and Nigro (in Radhika, 2012:25), Villoria et al.(2013), and Omisore and Adeleke (2015) who stated that organization structure, accountability, collaborative arrangements, existence of dissent channels, and efficient participation procedures, and trust in government administration can improve ethical behaviour of the public servants and citizen's satisfaction with government services.

The variable 'law/acts passed' has a significant influence on ethical behaviour in the regency of Sleman and has a rather significant influence in the city of Yogyakarta, and this supports Radhika's (2012) conclusion that legal framework, rule of law, and the principle of legality can boost ethical behavior among employees of a public organization.

The very relevant influence of the 'salary/incentives' variable on ethical behaviour in the regency of Sleman and in the regency of Bantul is in-line with the scholars' conclusion. Van Wart (in Radhika, 2012:25) argued that professional employees that are wellcompensated will exhibit stronger professional values and integrity. In addition, Omisore and Adeleke (2015) discussed about how work ethics, attitudes and values can be influenced by interventions like training, encouragement and coaching.

The very strong influence that the variable of 'culture' has on ethical behaviour in the regency of Sleman is verificationof many scholars' point of view. Dimock et al. (in Radhika, 2012:25) stated how influential an area's culture and virtues are to the behaviour of employees of an organization, and Schein (in Radhika, 2012:25) declared that cultural elements, such as artefacts, values, and assumptions, determine ethics in public administration. Omisore and Adeleke (2015) explained that ethical behaviour of public employees in providing public services is rooted in intrinsically held values. They stated that the work ethics an individual displays come from his/her values, that in addition, the values are dependent on their environment, experiences, and life-long influences, such as their parents, teachers, friends, peers, competitors, etc. Furthermore, Omisore and Adeleke (2015) cited that the ethical behaviors displayed during an employees' time at work is part of a cultural norm that places a positive value on doing a good job.

The strong influence of the 'religious beliefs' variable on ethical behaviour in the city of Yogyakarta confirmsof some the scholars' thinking. Bailey, Dimock et al., Schein (in Radhika, 2012:25), and Omisore and Adeleke (2015) asserted that the ethics of public servants of a government organization depends on beliefs, values, virtues, and mental attitudes that was prevalent and experienced during childhood and adolescence.

\section{Conclusion}

This study makes several important contributions. First, it empirically tests the effects that the independent variables 'democratic procedures', 'local autonomy/decentralization', 'leadership', 'organizational structure', 'laws/acts passed', 'salary/incentives', 'culture', and 'religious beliefs' have on the dependent variable of 'the ethical behaviour of the public servants in providing public services' in several local governments in Indonesia. Even though many experts in the field hold the opinion that the independent variables influence ethical behaviour, empirical studies on the matter are very scarce. Second, this study shows empirical proof that almost all of the independent variables affect the ethical behaviour of the 
public servants. Third, the findings of this study indicated that the influence of the independent variables on the dependent variable is varied in the scale between strong and weak in the three local governments.

The discoveries of this field study have practical implications especially for public organization officials and politicians in how they could better enhance ethical behaviour of government employees in providing public services. They should pay more attention to push more intensively on improving the democratic procedures in the regency of Sleman, the organizational structure style in the regency of Bantul, and the salary/incentives scheme in the city of Yogyakarta.

Even though this study makes significant contributions for the literature in the field of public organization studies and for practitioners in a government organization, this study has several limitations. First, this study extends the scope and meaning of the terms 'belief' (used as an independent variable) to the context of the Indonesian government and society, in which it is extended into 'religious beliefs'. Second, because of its relatively smaller size of respondent population, there may be problems with generalization and representation of this study. Third, because of the fact that this study used only questionnaires for getting the data instead of using public office archives and doing in-depth interviews of public officials, this study may receive some scientific criticism especially regarding triangulation of the data validity.

Further studies should be done to complement the weaknesses of this study. First, the following studies must use longitudinal investigation which will enable a continuity of inquiry into the phenomenon. Second, future studies must include other governments' public service institutions and wider samples. Third, future studies should aim to more completely explain the effects of the independent factors on the ethical behaviour of the public servants in providing public services using other relevant factors in other contexts.

\section{Acknowledgment}

First, the author would like to thank the Ministry of Research and Technology and Higher Education of the Republic of Indonesia, which has funded the author's research, in which this study is a part of. Second, the author would like to thank his colleagues at Universitas Muhammadiyah Yogyakarta, who have supported and assisted him in finishing his research. Finally, the author would also like to thank the government officials, the political actors, who have allowed him to carry out this study in their organizations, and the recipients of government public service who were willing to be respondents of this study.

\section{References}

Beeri, I., R. Dayan, E.Vigoda-Gadot, and S. B. Werner. (2013). Advancing Ethics in Public Organizations: The Impact of an Ethics Program on Employees' Perceptions and Behaviours in a Regional Council. Journal of Business Ethics 112(1): 59-78.

Budiman, A., A. Roan, and V.J. Callan. (2013). Rationalizing Ideologies, Social Identities and Corruption Among Civil Servants in Indonesia During the Suharto Era. Journal of Business Ethics 116 (1): 139-149. 
Cowell, R., J.Downe, and K. Morgan. (2014). Managing Politics? Ethics Regulation and Conflicting Conceptions of "Good Conduct. "Public Administration Review 74(1): 2938.

Gaus, N., S. Sultan, and M. Basri. (2017). State Bureaucracy in Indonesia and its Reforms: An Overview. International Journal of Public Administration 40(8):658-669.

Hassan, S., R.Mahsud, G.Yukl, and G. E. Prussia. (2013). Ethical and Empowering Leadership and Leader Effectiveness. Journal of Managerial Psychology 28(2): 13346.

Hassan, S., B. E. Wright, and G. Yukl. (2014). Does Ethical Leadership Matter in Government? Effects on Organizational Commitment, Absenteeism, and Willingness to Report Ethical Problems. Public Administration Review 74(Iss. 3): 333-343.

Hoadley, M.C., and N. Hatti. (2016). Rational Choice and Morality of Corruption. Social Science Spectrum 2(3):164-170.

Idris, M., M. Ramli, A. Agustang, and A.I. Kesuma. (2015). Bureaucracy Ethics Based in Public Service Local Wisdom in Gowa. Mediterranean Journal of Social Sciences 6(6): 419-424.

Johnson, B. J. (2014). Codes of Ethics, Public Values, and What Public Servants Offer the Bureaucratic Compact. International Journal of Organization Theory and Behaviour 17 (4): 459-497.

KPK. (2018, January 3). Tindak Pidana Korupsi. Retrieved from: https://acch.kpk.go.id/id/statistik/tindak-pidana-korupsi.

Mahfud, M.A. (2016). The Implementation of Local Wisdom Siri'na Pacce as an Effort of Corruption Eradication In Indonesia. The 2nd Proceeding on Indonesia Clean of Corruption in 2020. December 9th 2016. Unissula Press. Pp. 181-188.

Mayer, D. M., K. Aquino, R. L. Greenbaum, and M. Kuenzi. (2012). Who Displays Ethical Leadership and Why Does It Matter? An Examination of Antecedents and Consequences of Ethical Leadership. Academy of Management Journal 55(1): 151-71.

Nugraha, A., Sumartono, Tj. Domai, Suryadi. (2015). Public Service Quality in Good Governance Perspective: Study on Publishing Trade License in South Tangerang City. International Journal of Applied Sociology 5(2):63-75.

Ombudsman of Republic of Indonesia. (2017). Exsecutive Summary. http://ombudsman.go.id/index.php/laporan/laporan-penelitian.html. 04/01/2018.

Omisore, B.O., and O.Adeleke. (2015). Work Ethics, Values, Attitudes and Performance in the Nigerian Public Service: Issues, Challenges and the Way Forward. Journal of Public Administration and Governance5(1).

Prabowo, T.J.W., P. Leung, and J.Guthrie. (2017). Reforms in Public Sector Accounting and Budgeting in Indonesia (2003-2015): Confusions In Implementation. Journal of Public Budgeting, Accounting \& Financial Management 29 (1):104-137.

Radhika, D. (2012). Ethics in Public Administration. Journal of Public Administration and Policy Research 4(2): 23-31.

Resick, C. J., M. B. Hargis, P. Shao, and S. B. Dust. (2013). Ethical Leadership, Moral Equity Judgments, and Discretionary Workplace Behaviour. Human Relations 66(7): 951-972. 
Sebola, M.P. (2014). Ethics in the South African Public Service: A Paradox of Culture, Politics and Ethics in the World of Work. J SocSci 40(3):295-304.

Stout, M. and J. M. Love. (2013). Ethical Choice Making. Public Administration Quarterly 37(2): 280-296.

Villoria, M., G. G. Van Ryzin, and C. F. Lavena. (2013). Social and Political Consequences of Administrative Corruption: A Study of Public Perceptions in Spain. Public Administration Review 73(1): 85-94.

Walumbwa, F. O., D. M. Mayer, P. Wang, H. Wang, K.Workman, and A. L. Christensen. (2011). Linking Ethical Leadership to Employee Performance: The Roles of LeaderMember Exchange, Self-Efficacy, and Organizational Identification. Organizational Behaviour and Human Decision Processes 115(2): 204-13.

Wardhani, R., H. Rossieta, and D. Martani. (2017). Good governance and the impact of government spending on performance of local government in Indonesia. International Journal of Public Sector Performance Management 3(1): 77-102. 